\title{
Gill Epithelium Ultrastructure of Oreochromis niloticus Exposed to Gradual Raised Salinity
}

\author{
Cleverson Agner Ramos ${ }^{1}$, Marisa Fernandes de Castilho ${ }^{2}$ and Daiane Martins ${ }^{3}$ \\ 1. Department of Morphology, Federal University of Amazon (UFAM), Manaus, Amazon, Zip 6700, Brazil \\ 2. Department of Physiology, Federal University of Paraná, Curitiba (UFPR), P.O. Box 19031, Paraná, Brazil \\ 3. Post Graduation Program in Biotechnology, Federal University of Amazon (UFAM), Manaus, Amazon 6700, Brazil
}

Received: October 15, 2012 / Published: January 20, 2013.

\begin{abstract}
Fish gill is a multifunctional organ with role in acid-base balance, elimination of nitrogen waste and mainly gas exchange and ion regulation. There is a high energetic coast for ionregulation in freshwater fish maintained in salt water but a raise in growing taxes was observed for some species. The freshwater Nile tilapia, Oreochromis niloticus, is widely used in aquaculture farmers and the aim of this study was to investigate the changes on the gill filaments ultrastructure in fish kept under different salinities. Alevins were obtained and transported to laboratory of studies in animal stress Federal University of Paraná. Established groups in 0\%, 16\%o and 32\% salt water with 12 animals in each one. After 30 days of exposition, the animals were anesthetized and the second gill arches were dissected and processed for scanning and transmission electron microscopy. The mitochondrial rich cells fractional area and density in the gill epithelia were determinated. The under scanning electron microscopy (SEM) in $0 \%$ salinity group reveal changes in the apical ridge of mitochondrial rich cells (MRCs). In all other groups, the observations revealed numerous crypts disposed mainly in the filament epithelia. In transmission electron microscopy (TEM) two distinct types of MRCs were observed. The data of MRCFA and density revealed in $0 \%$ and $16 \%$ values significantly elevated in comparison to $32 \%$. Despite these lower values, the density in the gill epithelia was higher. The main differences found between the groups revealed that fish exposed to $16 \%$ salinity have less MRCs aperture to the environment and are less related to ion regulation process.
\end{abstract}

Key words: Mitochondrial-rich-cells, gill-morphology, Nile-tilapia, gill fish.

\section{Introduction}

Fish gill is a multifunctional organ with functions of acid-base balance, elimination of nitrogen waste and mainly the gas exchange and ion regulation in order that an intrinsic relationship between these last couple can be established and described as osmorespiratory compromise [1]. In teleost, there are four pairs of gill arches, each one had directed to the external environment, many filaments disposed in a pair of lines. The filament supports and interconnects a great amount of lamellae, having an angle of $90^{\circ}$, at both sides which are the sites of gas exchange by the counter flow system [2]. With the advent of electron

Corresponding author: Cleverson Agner Ramos, professor, research fields: fish physiology and cell biology. E-mail: cleverson@ufam.edu.br. microscopy several cells could be observed in the gill filament being mainly composed by pavement cells (PCs), mucous cells (MCs) and the mitochondrial rich cells (MRCs) [3]. The PCs form a polygonal mosaic in the apical membrane turned to the environment called microridges showing a concentric arrangement [4]. Between the CPs edges, there are small crypts, which are common in the afferent surface of filament and in the interlayer region [5, 6]. By scanning electron microscopy, these crypts were identified as the MRCs apex [4, 7].

Despite the MRCs, Girard et al. [8] described that in fish adaptation to seawater environments, there are a raise in the number of MRCs and a notorious development of a citoplasmatic tubular reticular system. In freshwater environment, the tubular system 
is concentrated next to the cell apex without contact to external environment. On freshwater environment, adjacent cells have interdigitations with pre-existing MRCs. These cells are linked by permeable junctions directly to the tubular system of an adjacent cell. About the morphology of MRCs tubular systems, Perry [9] described two morphological distinct MRC, the alpha $(\alpha)$ and beta $(\beta)$ cells, which are well observed in electron microscopy. According to the author, the $\beta$ cells are found just in freshwater environments-teleosts. The molecular mechanism of ion exchange and electrogenic pumps in seawater and freshwater teleosts are suggested by Hirose [10] and it seems to be involved in freshwater fishes, several kinds of cells with a pronounced uptake of $\mathrm{Na}^{+}$and $\mathrm{Cl}^{-}$from environment. As in seawater fishes, there are liberation of these ions to environment and there are a occurrence of accessory cells next to MRCs which seems to be seawater adaptatation-related [6]. Dunel-Erb et al. [5] suggested that these cells present interconnected citoplasmatic process. Several studies showing the seawater adaptations have been performed in the last years [11-14], especially taking into account that marine environment can be used in fish culture and has been taught as an alternative due to the reduction of available fresh water in good conditions. In regions where brackish water and even salt water are available, the culture in such environment can be considered in order to adjust the water osmolites, $\mathrm{pH}$, hardness and temperature to a perfect condition to development of fishes. Despite the high energetic coast of osmoregulation in freshwater fish maintained in salt water being elevated than in fresh water [15], a raise in growing taxes was found in some species $[16,17]$. The freshwater Nile tilapia, Oreochromis niloticus, is widely used in aquaculture farmers. Although this specie show physiological adjustment to high salinity information about peculiarities of this process are scarce. An important question is how these animals can deal with osmotic homeostasis changes in waters having the salinity raised and the most important organ involved on these changes are the gills. Therefore, the aim of this study was to investigate the changes on the ultrastructure in gill filaments under raised salinities in order to make an inference on the energetic demand of Nile tilapia (O. niloticus) by observation in MRCs parameters-related.

\section{Materials and Methods}

Specimen of O. niloticus (30 days post hach) were obtained from aquaculture farmers and transported to laboratory of studies in animal stress Federal University of Paraná. For seven days, the animals were kept in a $500 \mathrm{~L}$ stock tank with controlled temperature and photoperiod, being fed ad libitum daily with commercial pellets (Nucon ${ }^{\circledR} 40 \%$ protein). After the acclimation animals were transferred to experimental aquariums with $50 \mathrm{~L}$ capacity where the same patterns of acclimation were maintained. Three groups were set in raised salinities concentration, $0 \%$, $16 \%$ and $32 \%$, with 12 animals in each one. During 30 days, animals were feed based in $3 \%$ of its body mass. After the experimentation period, the animals were anesthetized in Ethyl p-Aminobenzoate, 0.9 $\mathrm{mL} / \mathrm{L}$. The second gill arches were dissected, washed in saline solution $(\mathrm{NaCl} 0.9 \%)$ and fixated in glutaraldehyde (GTA) 3\% buffered in sodium cacodylate $(0.2 \mathrm{M})$, at $\mathrm{pH} 7.4$.

\subsection{Scanning and Transmission Electron Microscopy}

The samples were washed in distilled water being dehydrated in ascending series of ethanol being dried in $\mathrm{CO}_{2}$ critical point (Bal-Tec CPD03). The samples were glued in a SEM stub and coated with gold in a vacuum sputter (BALZERS-SCD 030) and examined in a DSM 940 ZEISS scanning electron microscope at $25 \mathrm{kV}$.

For transmission electron microscopy (TEM), samples of individual filaments (1 $\mathrm{mm}$ long), GTA-fixed were post-fixed in $1 \%$ osmium tetroxide buffered to $\mathrm{pH} 7.3$ in the same buffer, washed with 
$0.9 \% \mathrm{NaCl}$ solution, stained in block with uranyl acetate, washed with $0.9 \% \mathrm{NaCl}$ solution, dehydrated in a graded acetone series and embedded in SPURR (EMS). Semi-thin sections were stained with toluidine blue and examined under an Olympus-Micronal photomicroscope. Ultra-thin sections were stained with uranyl acetate and lead citrate and examined with a JEOL JEM1200-EXII transmission electron microscope at $80 \mathrm{kV}$.

\subsubsection{MRC Density and Fractional Area}

The mitochondrial rich cells fractional area (MRCFA) and its density in the gill epithelia were determinate by measurement of 20 random fields observed in SEM, obtained according to Bindon [18] and Moron [19]. Using the SigmaScan Pro 3.0 (Jardel Scientific Inc.), the perimeters of MRCs were determined in each field observed in SEM. There were performed a comparison between the groups, according to the following equation:

$$
\text { MRCFA }=\frac{\sum \text { all MRCs area in field }}{\text { Field total area }}
$$

\subsection{Statistical Analysis}

The obtained data were expressed as mean \pm SEM and the statistical significance of the differences between the groups were determined using analysis of variance (ANOVA). The Tukey test with 95\% confidence limits was applied to compare the means whenever there was a significant difference (GraphPad InStat Software, San Diego, CA).

\section{Results}

\subsection{Scanning Electron Microscopy}

The morphological observations under SEM in animals, $0 \%$ salinity-exposed showed mainly changes in the apical ridge of MRCs, its diameter and the microridges on the pavement cells in the filament and lamellae epithelium. At all salinities exposed groups, observations under low magnification revealed numerous crypts disposed mainly in the filament epithelia (Fig. 1). No visible content was observed even in higher magnifications, therefore such crypts could be the apex of mucous cells. MRCs were found only in the gill filament but not in the lamellae. The MRC morphology under SEM revels as a crypt witch shows filamentous and granular projections, forming the apical crest of MRC. These cells have the opening for the medium with different diameters of apical ridge and its diameter varies along the gill epithelium (Figs. 1B and C). Pavement cells of the gill epithelia have microridges on the apical membrane which are partly degraded on the filament and completely degradated on the lamellae. The thickness of these structures was irregular and in some cells, it seems to have a fusion of such structures (Fig. 1D).

At $16 \%$ salinity, in lower magnifications were observed the same morphological features to those in $0 \%$ salinity exposed. The gill filaments also showed a high amount of crypts with no visible content (Fig. 1). Contrasting the previous group, the MRCs were not so discernible; therefore, there are few cells in the gill filament being just found in the lamellae. About its morphology, it was common to observe very well developed filamentous/granular apical projections and was also observed in various diameters (Fig. 2). The microridges also showed as a degraded ultrastructure at mostly filament pavement cells. Its thickness also was irregular with a fusion aspect (Fig. 1A-1C). The animals $32 \%$ salinity exposed also showed the same morphological features to despite the cryps at gill ephitelia with an empty its content (Fig. 1), MRCs distributed in the whole filament showing a developed apical crypt (Fig. 2). At this salinity, the microridges from lamellae are scarce and with a frayed aspect analogous from those of the filaments with have digitiform patterns (Fig. 1D).

\subsection{Transmission Electron Microscopy}

Under TEM observations, were found two distinct types of MRCs, the alpha $(\alpha)$ and the beta $(\beta)$ MRCs (Fig. 3). According to their morphology, the $\alpha$ MRCs 


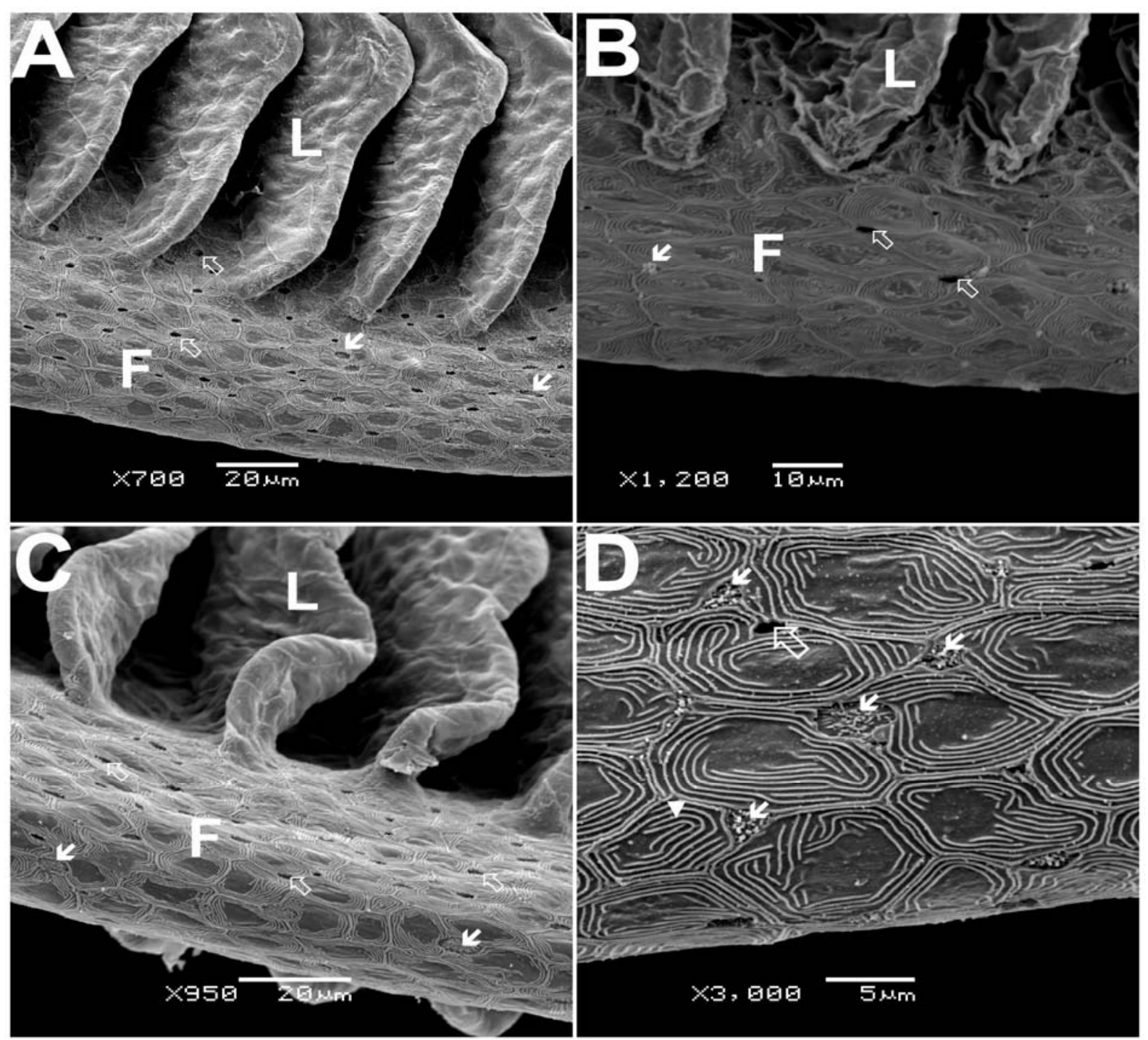

Fig. 1 Animals exposed to $0 \%$, 16\% and 32\% salinity, A, B and C respectively. Can be observed along the whole filament (F) several holes of MRCs and MCs and a well-developed lamellae $(L)$ in " $A$ " as in " $B$ " and " $C$ ", the epithelial cells morphology are slight altered. "D" represented the three main kinds of cell to be found in a gill epithelia $(\mathrm{MRCs}=\boldsymbol{K}, \mathrm{PCs}=\boldsymbol{\nabla}, \mathbf{M C}=\Xi)$. Can be observed in some of PCs, a lack of microridges in the apical surface as the CPs edges are well developed.

showed a great amount of mitochondria in its cytoplasm with a well distributed tubular system attached to the mitochondria. This feature leads to an electrodense cytoplasm. The $\beta$ MRCs have a large number of mitochondria, comparated to $\alpha \mathrm{MRCs}$, and their organelles are more developed than those from $\alpha$ cells. Their tubular system is short and low frequent at the cytoplasm becoming less eletrodense in comparison to $\alpha$ MRCs. Despite the differences observed on increasing of salinity, was observed in animals exposed to $32 \%$ (Fig. 3B) numerous $\alpha$ MRCs.
However, in animal exposed to $0 \%$ and $16 \%$, the most common MRC observed were the $\beta$ type.

\subsubsection{MRC Density and Fractional Area}

After measurement and processing of data to MRCFA and density (Fig. 4), were observed in animals exposed to $0 \%$ and $16 \%$ values significantly elevated $(P \leq 0.001)$ in comparison to animals exposed to $32 \%$. Despite these animals showed lower values of MRCFA, the density of these cells in the gill epithelia were higher in animals exposed to $0 \%$ and $16 \%$ o salinity. 

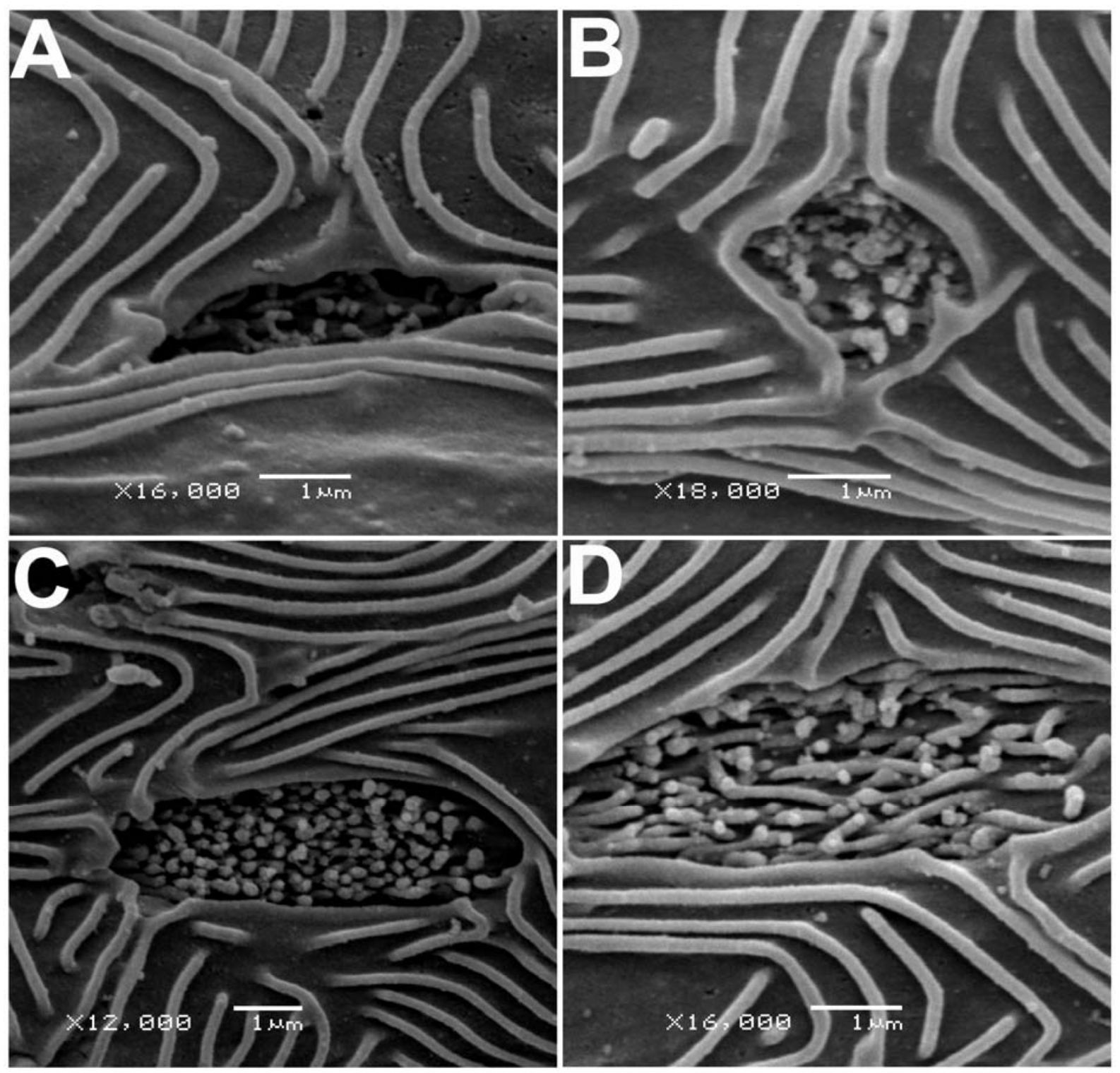

Fig. 2 Morfology of MRCs observed in the gill epithelia of $O$. niloticus; can be observed that MRCs have different diameter on apical surface as reflect of its activity; "A" can be observed a MRC with an apical cript while "B", "C" and "D" were observed projections of the apical pit supposing these cells having a wide surface contact to the environment.

\section{Discussion}

The main differences found between the salinities where the animals were exposed can provide inferences about the morphological changes of MRCs and their distribution on the gill filament. 16\% salinity, in small magnifications by SEM, was observed that these fish showed low occurrence of these cells compared to other salinities as well the occurrence of $\alpha$ and $\beta$ cells. 32\% salinity was observed only the presence of $\alpha$ cells, and apical crest still developed more than other salinities. Avella et al. [20] described the absent of MRCs in lamellae and in the filament they are scarce. These cells expose only a small surface to environment and their ultrastructure did not suffer alterations after transferred to $20 \%$ salinity. These cells also showed the tubular reticular system intact, reflecting their osmoregulatory potential. At $32 \%$ salinity, these cells are well developed and were observed cells with many diameters on its apical surface area (Figs. 1 and 2). 


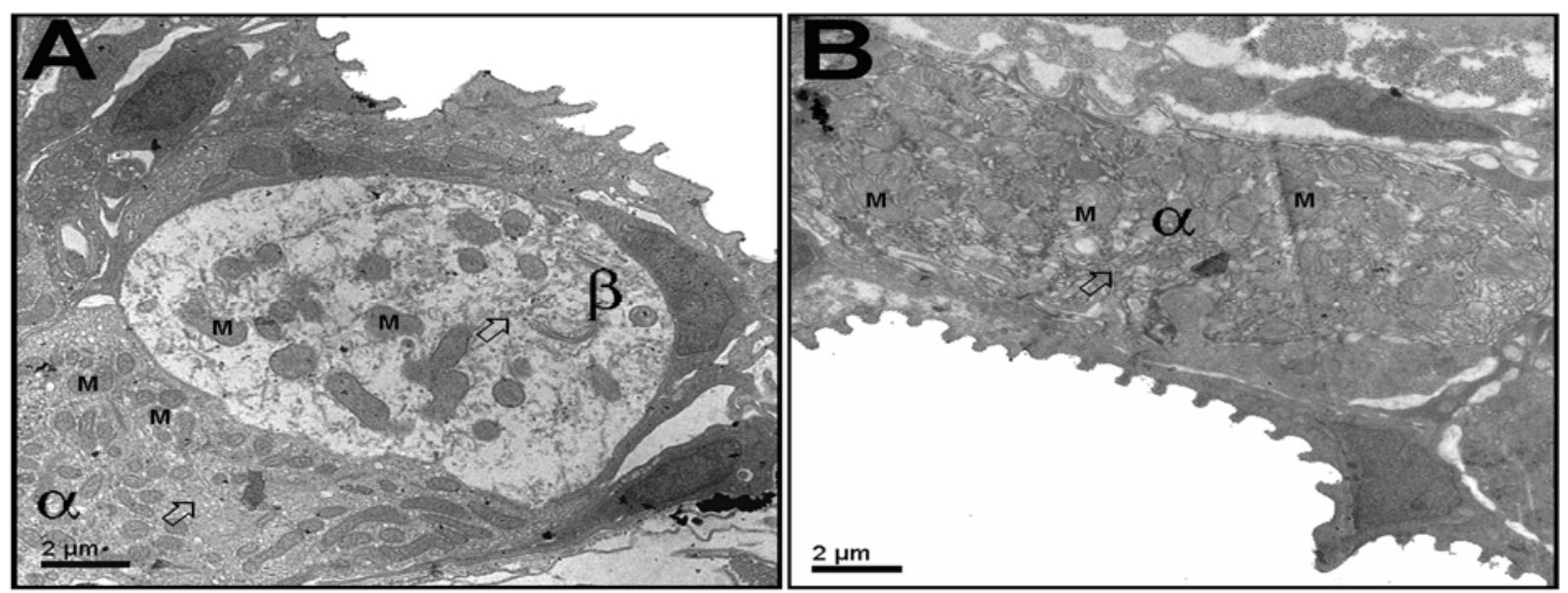

Fig. 3 CRMs morphology observed at TEM; "A" a MRC observed in fish exposed to 16\% described as $\alpha$ cell. This cell shows an electrodense cytoplasm with a large amout of mitochondria $(M)$ and a tubular system $(\Rightarrow)$ well aggregated. The $\beta$ cells show a lower number of mitochondria (M) however with a large size and a well distributed tubular system $(\Rightarrow)$ as observed in B, a MRC in animal exposed to 32\% salinity.
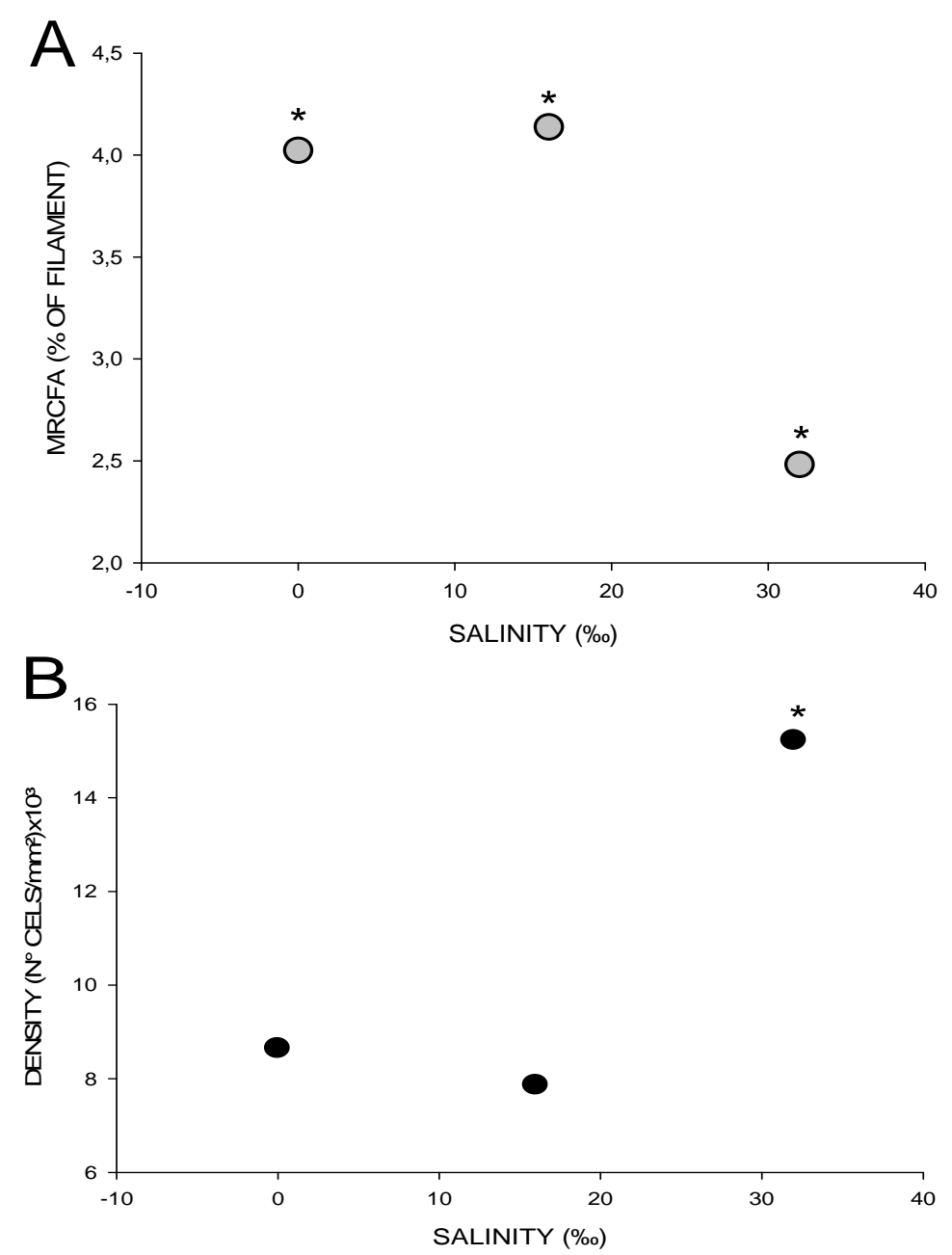

Fig. 4 MRCs fractional area (\% of filament) are showed that " $A$ " can be observed in animals exposed to $0 \%$ and $16 \%$ salinity values significantly elevated than specimen exposed to 32\%. "B" showed the density of MRCs in the filament epithelia which is elevated in animals exposed to $32 \%$ with lower values. 
The features of distribution of MRCs under different salinities allow us to suggest that in $16 \%$ salinity there is a low energy cost for osmorregulatory process since at this salinity the MRCs observed were scarce when in comparison to other salinities. Probably the condition of $16 \%$ salinity are close to the osmotic homeostasis this specie, thus the energetic demand in this condition is lower. Therefore, this environment would be suitable to management in aquaculture systems. According to Hirose et al. [10], in a typical freshwater fish, there are a large amount of MRCs involved on ion uptake from environment since the fish are hypertonic. At condition of 32\% salinity saltwater fish also shows a large amount of MRCs, however, these holes are different. These cells are involved on the ion elimination to environment since the fish in this condition is hypotonic.

At $16 \%$ salinity, the energy spared by keeping osmotic homeostasis can be directed to growth and mass gain. The suggestion of these cells as a suitable parameter on inferences to energy consumption is due to the fact of these cells show wide activity of transport proteins at their basolateral membranes [3, 10] and the energy losses occur during the ATP hydrolysis for the activity of ATPases. Boeuf and Payan [15] suggested that the energetic cost for ion regulation increases with salinity changes from isosmotic conditions.

Considering the localization and incidence of MRC, our findings demonstrated that these cells are distributed throughout the primary lamella. This distribution contrasts observations of Perry [9] which suggests that these cells occurs mostly in the region between filament and lamellae. Hossler [4] suggests that in afferent surface of filament as well in the interlamelar region, the MRCs are numerous as results observed by the present study. According to the author, these cells can be observed in the lamellae, however, in the present study, these cells are mainly in the fillament region. At SEM, the MRCs morphology has its characteristic by forming a crypt on the edge of pavement cells. Frequently, these crypts have filamentous/granular projections increasing the contact surface to the environment. Same observations were desbribed by Hossler [7] and Perry [9].

Several studies have proposed molecular models to the proteins of these cells which are involved to ion exchange. There are unique characteristics on these proteins in freshwater and marine environments [3]. These proteins in the gills have distinct roles in such environments and can interfere on the gill morphology as demonstrated by Hossler [4] which studding Fundulus heteroclitus adapted to marine environment suggests that MRCs have deeply rounded crypts with almost none ultrastructural feature. Fundulus heteroclitus adapted to freshwater the MRCs are less frequent and have larger aperture to the environment in comparison to fish saltwater adapted. These cells also show inside the crypt ultrastructural projections.

In the present study, it was observed a great variation on the aperture size of MRCs in all experimental conditions. At $0 \%$ and $32 \%$, the same filament could be observed in the small aperture of MRCs internal projections into the crypt with a granular aspect, instead filamentous. The MRCs with large diameter of aperture was observed inside the crypt filamentous projections. These groups were also observed in MRCs with a small aperture, geometric shape of crypts as in MRCs with large aperture was observed elliptic shape of the crypt.

At the $16 \%$ salinity, the MRCs had rounded shape and instead a crypt, they formed an apical crest. The projections of its crest showed granular projections. Laurent and Dunel [6] suggested that MRCs can be a differentiated epithelial cell originated from lamellae and filament which are numerous in specimen during its development as in adults. Thus, it can be considered the hypothesis that this difference in size of MRCs could be reflected of the stage of development of this fish since they were alevins.

The observation by TEM can be inferred that MRCs observed in 16\% and 32\% follow the pattern 
described by Pisam et al. [21], being observed the occurrence of $\alpha$ and $\beta$ MRCs in 16\% salinity and only the occurrence of $\alpha$ MRCs in 32\% salinity. According to the author with the raise of salinity the $\beta$ MRCs became apoptotic resulting in the gills only $\alpha$ MRCs which became responsible for ion regulation in elevated salinities. Pisam et al. [22] suggested that prolactin (ti-PRL I), an essential hormone for adaption in saltwater, plays a role in $O$. niloticus during the adaptation in brackish water in order to change $\beta$ MRCs to $\alpha$ MRCs. Similar observations about the ultrastructure of MRCs were described by Maina [23] which describes two subtypes of MRCs, the light and the dark MRCs. The ultrastructural features of these cells are very clear but the molecular features of these cells during the transition from freshwater to saltwater are less studied.

About the microridges, these structures are described as a feature of gill epithelia in fish recognized by several studies [24]. Despite to be such a peculiar structure there is still no evidence of its function. Eiras-Stofella [25] suggested these structures to increased respiratory surface. Other function suggested by the author was that such structure could be allowed a better distribution of mucous secreted by mucous cells through the epitelial gill or still protect against infestation by parasites. The microridges found in the gills of $O$. niloticus showed a concentric pattern as described for several authors [4, 7, 25]. Our findings, corroborates several studies described a lack of alterations in microridges morphology related to changes in the salinity of environment $[4,7$, 26-28].

About the mucous cells, was observed very numerous cells in the filamento and there are no diferences on its morphology related to changes in the salinity. According to Eiras-Stofella [25], the mucous cells seem to preserve the ultrastructure of gill. This secretion is a fast response from external stimulus, so when the fish is in contact to anesthesic, or during the dissection of branchial archs, these cells secreted its mucous. Thus there is no relationship between the mucous cells observed and the changes on the salinity.

Studies about osmoregulatory process in saltwater environments have been described to O. mossambicus by Avella et al. [20] and Nolan et al. [29], which consider $O$. mossambicus adaptable to salinity variation based upon cortisol levels as the plasmatic glucose typical of unstressed fish. The authors suggested a hydro mineral equilibrium in this specie by the enzymes of MRCs in fish exposed to saltwater and freshwater. The author observed even after fish confined to marine environment a reduction on $\mathrm{Na}^{+} / \mathrm{K}^{+}$ATPase in gills with observations of apoptotic process in CRMs on filament region. For this specie, Vonck et al. [30] observed in the opecular epithelia a reduction in the density of MRCs in fish keep at a salinity of $50 \%$ saltwater and higher values were obtained in fish kept in freshwater and saltwater being the last one significant higher than freshwater. Furthermore, the branchial $\mathrm{Na}^{+} / \mathrm{K}^{+}$ATPase activity was lower in fish kept in 50\% saltwater and elevated in fresh and saltwater.

\section{Conclusions}

The obtained data corroborate the hypothesis that variations on the ultrastructure of filament could be related to variation of development in fish during exposition in different salinities. Thus, the lower occurrence of MRCs in 16\% salinity could be provided a less energetic losses for osmoregulatory process when animals were exposed and cultivated in this salinity.

\section{References}

[1] S. Nilsson, Control of gill blood flow, in: S. Nilsson, S. Holmgren (Eds.), Fish Physiology: Recent Advances, Croom Helm, London, 1986, pp. 86-101.

[2] Q. Bone, N.B. Marshall, J.H.S. Blaxter, Biology of fishes, 1995 , p. 332.

[3] D.H. Evans, P.M. Piermarini, W.T.W. Potts, Ionic transport in the fish gill epithelium, J. Exp. Biol. A. 283 (1999) 641-652.

[4] F.E. Hossler, Gill arch of the mullet, Mugil cephalus, III. 
Rate of response to salinity change, Am. Physiol. Soc. 238 (1980) 160-164.

[5] S. Dunel-Erb, P. Laurent, Ultrastructure of marine Teleost gill epithelia: MEV and MET study of the chloride cell apical membrane, J. Morphol. 165 (1980) 175-186.

[6] P. Laurent, S. Dunel, Morphology of gill epithelia in fish, Am. Physiol. 238 (1980) 147-159.

[7] F.E. Hossler, G. Musil, K.J. Karnaky, F.H. Epstein, Surface ultrastructure of the gill arch of the killifish, Fundulus heteroclitus, from sewater and freshwater, with special reference to the morphology of apical crypts of chloride cells, J. Morphol. 185 (1985) 377-386.

[8] J.P Girard, P. Payan, Ion exchange through respiratory and chloride cells in freshwater- and seawater-adapted teleosteans, Am. Physiol. Soc. 238 (1980) 260-268.

[9] S.F. Perry, The chloride cell: Structure and function in the gills of freshwater fishes, An. Rev. Physiol. 59 (1997) 325-347.

[10] S. Hirose, T. Kaneko, N. Naito, Y. Takei, Molecular biology of major components of chloride cells, Comp. Bioch. Physiol. B. 136 (2003) 593-620.

[11] J.S Likongwe, T.D. Stecko, J.R. Stauffer, Combined effects of water temperature and salinity on growth and feed utilization of juvenile Nile tilapia Oreochromis niloticus (Linneaus), Aquacult 146 (1996) 37-46.

[12] M.R.R. Romana-Eguia, R.V. Eguia, Growth of five Asian red tilapia strains in saline environments, Aquaculture 173 (1999) 161-170.

[13] W. Watanabe, D. Ernst, B. Olla, R. Wicklund, Aquaculture of red tilapia Oreochromis sp. in marine environments: State of the art, in: Advances in Tropical Aquaculture, 1989, pp. 487-498.

[14] M. Yan, Z. Li, B. Xiong, J. Zhu, Effects of salinity on food intake, growth, and survival of pufferfish (Fugu obscurus), J. Appl. Ichthyol. 20 (2004) 146-149.

[15] G. Boeuf, P. Payan, How should salinity influence fish growth?. Comp. Bioch. Physiol. 130 (2001) 411-423.

[16] B. Fauconneau, S. André, J. Chmaitilly, P.Y. Le Bail, F. Krieg, S.J. Kaushik, Control of skeletal muscle fibres and adipose cells size in the flesh of rainbow trout, J. Fish Biol. 50 (1997) 296-314.

[17] T.M. Jonassen, A.K. Imsland, S.O. Stefansson, The interaction of temperature and fish size on growth of juvenile halibut, J. Fish Biol. 54 (1997) 556-572.

[18] S.D. Bindon, J.C. Fenwick, S.F. Perry, Branchial chloride cell proliferation in the rainbow trout, Oncorhynchus mykiss: Implications for gas transfer, Can J. Zool 72 (1994) 1395-1402.

[19] S.E. Moron, E.T. Oba, C.A. De Andrade, M.N. Fernandes,
Chloride cell responses to ion challenge in two tropical freshwater fish, the erythrinids Hoplias malabaricus and Hoplerythrinus unitaeniatus, J. Exp. Biol. 298 (2003) 93-104.

[20] M. Avella, J. Berhaut, M. Bornancin, Salinity tolerance of two tropical fishes, Oreochromis aureus and $\mathrm{O}$. niloticus. I. Biochemical and morphological changes in the gill epithelium, J. Fish Biol. 42 (1993) 243-254.

[21] M. Pisam, A. Caroff, A. Rambourg, Two types of chloride cells in the gill epithelium of a freshwater adapted euryhaline fish: Lebistes reticulatus, their modifications during adaptation to saltwater, Am. J. Anat. 179 (1987) 40-50.

[22] M. Pisam, B. Auperin, P. Prunet, F. Rentier-Delrue, J. Martial, A. Rambourg, Effects of prolactin on $\alpha$ and $\beta$ chloride cells in the gill epithelium of the saltwater adapted tilapia "Oreochromis niloticus", Anat. Rec. 235 (1993) 275-284.

[23] J. Maina, A morphometric analysis of chloride cells in the gills of the teleost Oreochromis alcalicus and Oreochromis niloticus and a description of presumptive urea-excreting cells in O. alcalicus, J. Anat., 1991, p. 175.

[24] F.E. Hossler, J.R. Ruby, T.D. McIlwain, The gill arch of the mullet, Mugil cephalus, I. Surface ultrastructure, J. Exp. Biol. 208 (1979) 379-397.

[25] D.R. Eiras-Stofella, Variabilidade morfológica da região faríngea dos arcos branquiais de algumas espécies de peixes (Teleostei), estudada através da microscopia eletrônica de varredura, Doctoral Thesis, Universidade Federal do Paraná, 1994.

[26] P.A. Crocker, M. Gotto, J.A. Deboer, Notes on the surface structure of the gill arch epithelium in juvenile red drum, Sciaenops ocellatus exposed to salt and freshwater, Copeia 2 (1985) 515-518.

[27] L. Fishelson, Scanning and transmission electron microscopy of the squamous gill filament epithelium from fresh and seawater adapted Tilapia, Envir Biol Fish 5 (1980) 161-165.

[28] F.E. Hossler, J.H. Harpole, J. King, The gill arch of the striped bass, Morone saxatilis. I, Surface ultrastructure, Submicr Cytol 18 (1986) 519-528.

[29] D.T. Nolan, R.L.J.M. Op'T-Veld, P.H.M. Balm, S.E. Wendelaar-Bonga, Ambient salinity modulates the response of the tilapia, Oreochromis mossambicus (Peters), to net confinement, Aquacult 177 (1999) 297-309.

[30] A.P.M.A. Vonck, S.E.W. Bonga, G. Flik,. Sodium and calcium balance in Mozambique tilapia, Oreochromis mossambicus, raised at different salinities, Comp. Bioch. Physiol. A. 119 (1998) 441-449. 